\title{
Do exclusivismo ao inclusivismo: a virada da igreja católica frente à diversidade religiosa
}

From exclusivism to inclusivism: the turn of the Catholic church towards religious diversity

Antônio Lopes Ribeiro*

\begin{abstract}
Resumo
Uma religião aberta em seu início, jamais impermeável às outras religiões, o cristianismo recrudesceu-se sobre si mesmo ao tornar-se religião oficial do Império Romano. Isto tem um motivo: a fim de unificar politicamente o Império, o imperador romano proibiu qualquer expressão religiosa que não fosse cristã. Assim, o cristianismo tornou-se soberano na Cultura Ocidental, onde foi gestado, posicionando-se como única e verdadeira religião. No cristianismo católico, esse monoculturalismo religioso é simbolizado pelo velho axioma: extra ecclesiam nulla salus. Sob o pretexto de ser depositária exclusiva da fé cristã, a Igreja católica historicamente se afirmou como única via possível de salvação frente às expressões cristãs cisionárias e também frente às religiões não cristãs, defendendo um retorno à barca de Pedro, no âmbito do cristianismo, ou propondo às outras religiões, a formação de uma única civilização cristã, num processo de aglutinação de todas elas, em torno de si. Este artigo trata sobre a virada de página dessa posição da Igreja católica, que se deu no Vaticano II, obrigando-a a se desvencilhar dessa camisa de força à qual estava submetida, saindo de um acentuado exclusivismo para uma experiência de inclusão religiosa, lançando-se positivamente ao encontro com a diversidade e pluralidade religiosa.
\end{abstract}

\section{Palavras-chave}

Cristianismo. Pluralismo religioso. Exclusivismo. Inclusivismo.

\begin{abstract}
An open religion at first, never permeable to other religions, Christianity closed in itself when it became the official religion of the Roman Empire. This happened for a reason: in order to politically unify the Empire, the Roman Emperor prohibited any other religious expressions but the Christian ones. Therefore, in the Western Culture where it was born, Christianity became the sovereign and assumed the position of the only and true religion. The old axiom: extra
\end{abstract}

* Doutorado em Ciências da Religião (PUC-GO); Mestrado em Ciências da Religião (PUC-GO); Especialização em Diálogo Ecumênico e Inter-religioso (FAJE/ITESC); Graduação em Teologia (FATEODF); Graduação em Pedagogia (UCB); Professor da Faculdade de Teologia da Arquidiocese de Brasília FATEO; Professor do Seminário Missionário Arquidiocesano Redemptoris Mater - RMATER, da Arquidiocese de Brasília; Pesquisador do Grupo de Estudos e Pesquisa em Educação, Religião, Cultura e Saúde - GEPERCS, da Universidade do Estado da Bahia (UNEB); Membro da Sociedade de Teologia e Ciências da Religião - SOTER. Atualmente é pesquisador pela PUC-PR - Pós-doutorando em Teologia. Email: lopesribeiroa@gmail.com. 
ecclesiam nulla salus symbolizes this Catholic Christianity religious monoculturalism. On the pretext of being the exclusive depositary of the Christian faith, the Catholic Church historically stated it was the only possible way to salvation in the face of dividing Christian religions and non-Christian ones. Therefore, it advocated a return to Peter's boat in the scope of Christianism, or proposed to the other religions to form a single Christian one by the union of all of them around it. This article covers the Catholic Church abandonment of this position, which took place in the Vatican II when it was forced to get rid of the straitjacket that hindered it. This way it left a strong exclusivism to experiment religious inclusion by positively meeting diversity and religious pluralism.

\section{Keywords}

Christianism. Religious pluralismo. Exclusivismo. I nclusivism.

\section{Introdução}

Ao longo de sua história, a Igreja católica assumiu duas visões de mundo na sua forma de relacionar-se com outras expressões da fé cristã e com as religiões não cristãs: uma exclusivista, com centralidade eclesial, e outra inclusivista, centrada na pessoa de Cristo.

De religião aberta em seu início, jamais impermeável às outras religiões com as quais entrou em contato, o cristianismo recrudesceu-se sobre si mesmo ao tornar-se religião oficial do Império Romano. Isto tem um motivo: para unificar politicamente o Império, o imperador romano proibiu qualquer expressão religiosa que não fosse cristã, em todo território a ele pertencente. Assim, o cristianismo tornou-se soberano na Cultura Ocidental, onde foi gestado, posicionando-se como única e verdadeira religião.

Na Igreja católica, esse monoculturalismo religioso é simbolizado pelo velho axioma: extra ecclesiam nulla salus. Com efeito, sob o pretexto de ser depositária exclusiva da fé cristã, a Igreja católica historicamente se afirmou como única via possível de salvação frente às expressões cristãs cisionárias e também frente às religiões não cristãs, com as quais entrou em contato. Com relação aos cristãos separados, defendia um retorno à barca de Pedro (que encontra paralelo na arca de Noé), propondo às religiões não cristãs a formação de uma única civilização cristã, num processo de aglutinação de todas elas, em torno de si.

Este artigo trata sobre a virada de página dessa posição da Igreja católica, que se deu no Vaticano II, que "marca uma época na percepção da Igreja e da sua presença no mundo" (SANTORO, 2004, p. 61), obrigando-a a desvencilhar-se de uma camisa de força à qual estava submetida, saindo de um acentuado exclusivismo para uma experiência de inclusão religiosa, lançando-se positivamente ao encontro com a pluralidade eclesial e a diversidade religiosa. 


\section{O Cristianismo como experiência cultural: as duas visões de mundo da Igreja Católica}

Falar sobre o cristianismo como realidade cultural é reconhecer a influência deste sobre as culturas. Ainda que tenha nascido no Oriente, o cristianismo tornou-se a grande religião que é, na cultura Ocidental, sendo influenciado fortemente por ela, sobretudo na sua forma de organizar-se eclesiasticamente e, ao mesmo tempo, impregnando-a com seus valores de tal forma que equivale a dizer que a cultura do Ocidente é uma cultura essencialmente cristã. Mas, há de se observar que ainda que tenha assimilado tantos elementos da cultura Ocidental (com destaque para a riqueza do direito canônico), o Cristianismo a transcende. Assim, mesmo que se expresse culturalmente, como veremos logo adiante, por ter um caráter universal, como religião revelada, o Cristianismo se afirma como sendo totalmente independente da cultura na qual foi gestado, não se reduzindo à mesma, sendo, portanto, supracultural.

Contudo, o cristianismo não é um sistema universal, estático e imutável, desligado do concreto e do real, como se fosse apenas um conjunto de ideias e sentidos, de valores e princípios, o que leva à afirmação de que no nível da experiência humana, é uma realidade marcadamente cultural. ${ }^{1}$ Isto se verifica no dado histórico da encarnação do Filho de Deus que, por sua universalidade, se aplica como verdade de fé a todas as culturas, o que faz com que o cristianismo, em sua consistência humana, seja uma vivência cultural, porque “toda a concretização histórica de nossa fé cristã só se realiza efetivamente no contexto de uma ou mais culturas" (AZEVEDO, 2001, p. 19).

O homem é um ser religioso e ao mesmo tempo cultural. Não se separa a realidade cultural de sua religiosidade. Faz parte de sua identidade dizer, por exemplo, que é brasileiro, argentino, uruguaio, chileno, peruano etc, e que professa a fé cristã. A crença do homem não se dissocia de sua cultura. Ao contrário, uma está sempre em interação com a outra. Uma marca da virada antropológica na teologia católica, devida a Karl Rahner, consiste em que "a reflexão sobre o ser humano não se separa da reflexão sobre Deus" e vice-versa. Uma realidade leva à outra. Como na cultura ocidental, no nível da crença, Deus é tido como existente, logo é um dos elementos da realidade, ou seja, constitutivo da cultura. Conforme Sanches (2004, p. 86), a relação se estreita mais ainda quando consideramos o conceito de pessoa no Ocidente, como imago Dei. Ou seja, Deus é pessoa e o ser humano, feito à sua imagem e semelhança, também é pessoa. Deduz-se disso que, o falar sobre Deus, na cultura Ocidental, reflete no conceito de humano e vice-versa. Daí a

\footnotetext{
${ }^{1}$ Segundo Sanches (2004, p. 29), a cultura "não pode ser reduzida a um setor da vida humana, pois ela 'é algo muito mais complexo e envolve o ser humano em todas as suas dimensões", inclusive a dimensão religiosa.
} 
afirmação de que o cristianismo é essencialmente cultural. Ele se impregna no seio da cultura de tal forma, que passa a fazer parte dela. ${ }^{2}$

Como neste artigo nos propomos a descrever a reação da Igreja católica frente às religiões não-cristãs, na sua missão evangelizadora, veremos, a seguir, as duas experiências que marcaram essa vertente do Cristianismo, ao longo de sua história, que vai do exclusivismo religioso, pautado por uma visão monocultural, exclusivista e eclesiocêntrica, conforme já mencionado na introdução, a uma visão monocultural, inclusivista e cristocêntrica, a se delinear no Concílio Vaticano II.

\section{Uma experiência monocultural: a visão exclusivista da Igreja Católica}

Definir o cristianismo como uma realidade monocultural equivale a dizer que por ter sido gestado numa cultura forte, como a do Ocidente, que se impõe ao mundo como única e verdadeira cultura, de igual modo, por ser uma religião forte frente às outras, também se apresenta ao mundo como única e verdadeira religião. Esta visão monocultural, execrada pelo papa Francisco na Evangelii Gaudium (cf. EG n. 93), é profundamente expressa na Igreja católica, no velho axioma "extra ecclesiam nulla salus" (fora da Igreja não há salvação). Mas isso constitui um grande paradoxo.

É fato histórico incontestável que Jesus tenha nascido Judeu, tenha sido criado e educado numa cultura hebreia, com a qual, naturalmente se identificava. Os escritos sobre Ele mostram a relação conflituosa que teve com as culturas de sua época. A centralidade de sua mensagem, bem como sua morte e ressurreição, somente se tornam compreensíveis se considerado o contexto da experiência religiosa do povo com o qual Ele conviveu. Embora, conforme ensina a história do cristianismo, Jesus tenha vindo com missão específica de libertar o povo judeu, e em razão disso tenha feito uso da linguagem e de toda a simbologia tradicional da cultura desse povo, Ele manteve contato com outros povos, como os siro-fenicianos, romanos, gregos e samaritanos (PIETRZAK, 2010, p. 2324). Portanto, Jesus viveu numa realidade multicultural, da qual nasceu a religião que o tem como ponto de referência máxima e como elemento fundante.

Foi nesse contexto multicultural que o Cristianismo nasceu. Em sua fase primitiva, era uma religião aberta. Ocupava-se do anúncio do querigma, sem excluir ninguém. Vista

\footnotetext{
2 Como exemplo disso, podemos citar a relação entre o cristianismo e a cultura popular, na luta pela libertação dos oprimidos na América Latina. Antônio Manzatto (1994, p. 327) é quem ilustra isso, ao afirmar que "a religiosidade popular, onde situa-se, evidentemente, o cristianismo popular, não é apenas religiosidade, mas síntese simbólica da vida do povo. Nesse sentido, ela liga-se à cultura popular que é a forma do popular organizar e viver sua vida". Desta forma, ao ligar-se à cultura popular, na América Latina, o cristianismo popular "manifesta-se como uma forma do povo simples resistir à dominação sociocultural que lhes é imposta; nesse sentido, trata-se de uma apropriação que o popular faz do cristianismo que lhe é apresentado pelos poderes dominantes para, na criatividade, transformá-lo, de maneira original, em força de resistência e de combate, onde Deus manifesta-se como estando ao lado dos dominados".
} 
à época como apenas um apêndice do judaísmo, pelos ideais que ensinava, aquela religião nascente ganhava adeptos de diversos lugares, não pela exclusão, mas pela atração. Contudo, foi crescendo e sofrendo transformações, nos anos que se seguiram à fase póspascal. Essas transformações acentuaram-se, principalmente quando as comunidades cristãs entraram em contato com a cultura grega e latina. Sob o domínio do Império Romano, o cristianismo sofreu grandes influências, organizando-se e institucionalizandose, definitivamente.

Tornada religião oficial do Império Romano, o Cristianismo passaria a ver o mundo com lentes exclusivistas, com afirmações monoculturais, e com centralidade não mais no querigma, mas na própria Igreja. Paulatinamente, o cristianismo latino foi se amadurecendo e se ocidentalizando durante todo o período da Idade Média européia. Essa forma de ser ocidental, que definiu a identidade do cristianismo como religião, tem uma dupla dimensão: uma religiosa e, como vimos anteriormente, outra cultural, ambas tecidas e integradas numa só realidade. De um lado temos um cristianismo forte que "define e constrói sua própria cultura e pauta por ela a sociedade em que se encontra". Por outro lado, "uma cultura bem definida condiciona e orienta o desabrochar de um cristianismo quase hegemônico e muito criativo" (AZEVEDO, 2001, p. 20).

Esse cristianismo gestado na cultura ocidental teve sua fase de difusão e expansão no processo de evangelização que se deu após o século XIII, até praticamente nossos dias. Nesse sentido, de modo não exclusivo, porém dominante, falamos aqui de um cristianismo monocultural, transmitido ao longo da história da Igreja, pela evangelização, com uma "fisionomia cultural concreta do cristianismo ocidental" (AZEVEDO, 2001, p. 21).

Num processo de deculturação, ${ }^{3}$ com a missão de levar a Boa Nova ao mundo, esse cristianismo se impôs como cultura dominante sobre todas as outras culturas alcançadas pela evangelização, que no caso da América Latina e Caribe se deu paralela à colonização, tendo como consequência maior, "uma simultânea justaposição entre o cristianismo, de um lado, e, de outro, as culturas de origem dos povos que iam sendo evangelizados, ao preço de uma crescente perda de suas próprias raízes culturais e religiosas" (AZEVEDO, 2001, p. 21).

Com efeito, por cinco séculos de colonização, a evangelização na América Latina e no Caribe, atrelada que estava ao modo como o Ocidente cristão tratava o "outro", simplesmente negou o exercício da alteridade, em sua relação com os 'evangelizados' (ou dominados). O contato do Ocidente cristão, com as culturas da América Latina e Caribe, por meio de sua maior vertente, a Igreja católica, nas missões promovidas pelos países ibéricos, no período colonial, se deu de forma violenta, envolvendo submissão, rejeição e

\footnotetext{
${ }^{3}$ Que consistia em substituir pela imposição (por força do poder da cruz e da espada) a religião de outras culturas, para dar lugar à única e verdadeira religião: o cristianismo.
} 
até mesmo o aniquilamento. Isso mostra como a missão evangelizadora, mesmo sob uma ação eclesial "sob o dinamismo do Espírito Santo não deixa de ser uma ação humana, sujeita às contingências da história, como qualquer outra ação” (BRIGHENTI, 2006, p. 5).

\section{A experiência multicultural}

Toda a experiência salvífica, assim como foi a própria vida de Cristo, implica uma abertura gratuita à alteridade e até mesmo ao altruísmo. Conforme ensina a teologia cristã, Cristo deu sua vida pelo outro, ensinando aos seus seguidores que o caminho para Deus é o caminho da alteridade e do altruísmo. Contudo, por mais que Ele tenha ensinado que se deve amar o outro como a si mesmo, como vimos, a história ensina que a Igreja que nasceu a partir Dele seguiu outros rumos. Hoje, os tempos são outros. O mundo tornou-se plural e diverso, em termos culturais e religiosos. Não há mais espaço para posições imperialistas, monoculturais e excludentes. Sabe-se que qualquer missão evangelizadora somente será eficaz, se sua ação tiver como ponto de partida o 'outro', "não como uma realidade passível de ser 'assimilada' ou 'rejeitada', nem muito menos como mero prolongamento do mesmo - do eu -, mas como o 'totalmente outro'”. Enfim, ver o outro "não como ameaça ou potencial inimigo, mas como instância de enriquecimento e de novas possibilidades" (BRIGHENTI, 2006, p. 5-6).

Desde essa perspectiva, torna-se um desafio para a própria Igreja católica colocarse no lugar do outro, acolher o outro, em atitude dialogal, resgatando o sentido do cristianismo como religião da alteridade. Isso leva necessariamente o cristianismo a uma experiência multicultural, em que a evangelização se dá no respeito ao outro e à sua cultura.

\section{O deslocamento de uma visão monocultural para multicultural: a Igreja católica se abe ao universo plural}

Nos dias de hoje, não há mais espaço para a Igreja continuar se posicionando frente às outras religiões, com a visão monocultural que a caracterizou por tantos séculos, num contexto em que através da globalização, abriram-se as fronteiras para o encontro das culturas. Vivemos na contemporaneidade um acentuado pluralismo cultural, ${ }^{4}$ contexto este em que a Igreja católica finalmente se abre ao mundo moderno e ao universo plural e

\footnotetext{
${ }^{4}$ O pluralismo cultural não pode ser visto hoje como escândalo ou ameaça para a unidade da Igreja, mas sim como um desafio. Desta forma, a Igreja que continua sendo o "sacramento do mundo", tem à sua frente um novo caminho a ser trilhado na evangelização do povo latino-americano-caribenho: a inculturação. Nessa nova empreitada religiosa, a Igreja poderá ser obstáculo ou caminho para a inculturação do Evangelho. A mesma se torna obstáculo para a inculturação do Evangelho "quando a sua universalidade fica abstrata e quando uniformidade é a estratégia principal para garantir a unidade e a catolicidade". A Igreja será o caminho da inculturação "quando a sua universalidade faz-se concreta, ousa afirmar os vínculos com todas as culturas segundo a forma cristã da kenosis" (PIETRZAK, 2010, p. 37).
} 
diverso das crenças, tendo como fio condutor a inculturação da fé cristã, no respeito às culturas outras, num verdadeiro exercício de alteridade, de forma tal a reparar a fratura entre fé e cultura, observada pelo papa Paulo VI, na Evangelii Nuntiandi, em que se referiu à realidade vivida pelos povos que foram anteriormente evangelizados pela Igreja Católica, que não conseguiu promover um encontro da Palavra de Deus, com a vida cotidiana das pessoas.

Correspondendo a uma virada antropológica no âmbito da Igreja católica, com a realização do Vaticano II, acontece o deslocamento de uma visão monocultural, eclesiocêntrica e exclusivista, para uma visão multicultural, cristocêntrica e inclusivista. Com efeito, a partir da realização do Concílio Vaticano II, a Igreja católica passa a reconhecer a presença de sinais salvíficos em outras denominações cristãs não católicas e também sementes do Verbo em outras religiões não-cristãs.

A seguir, a importância do Vaticano II para a formação de uma consciência inclusivista na Igreja católica, que mudará os rumos de sua missão de divulgar ao mundo a experiência salvífica de Jesus Cristo.

\section{O Vaticano Ii lança a Igreja Católica à pluralidade eclesial e à diversidade religiosa}

Ao promover uma profunda transformação na visão de mundo religiosa na Igreja católica, o Concílio Vaticano II rompeu com 400 anos de Contra-Reforma, que data desde o Concílio de Trento (século XVI), passando pelo Concílio Vaticano I (em fins do século XIX), até chegar àquele Concílio. Trata-se, porém, de uma ruptura mais teológica do que institucional, não resultando em mudanças estruturais no modelo eclesial.

O Concílio Vaticano II significou um progresso inegável para a Igreja e para o mundo, pois valorizou o povo de Deus; motivou uma participação maior dos leigos na ação missionária e na tomada de decisões em nível de comunidades; fomentou a criação de uma colegialidade episcopal; um Igreja-comunhão; uma presença maior no mundo; o respeito às culturas, bem como às etnias; uma maior sensibilidade aos problemas humanos; um maior empenho por uma sociedade fundada na justiça e na paz (MIRANDA, 2006, p. 13). Afirmada como 'sinal e instrumento de salvação' (LG 1) e por isso mesmo, com uma identidade aberta e voltada para o mundo, a Igreja católica se propõe dar aos homens imersos nas tristezas e angústias, 'alegria e esperança' (GS 1).

Pela primeira vez, em séculos, a Igreja convoca um Concílio não para decidir sobre uma verdade de fé ou condenar algum erro teológico, posicionando-se de forma apologética, como afirmou o papa Paulo VI (1997, p. 666) em seu discurso de conclusão do Concílio: “A Igreja, com efeito, entrando em si mesma, penetrou no íntimo da sua consciência não para se comprazer em eruditas análises sobre a psicologia religiosa ou a história das suas coisas, ou para intencionalmente reafirmar os seus direitos ou formular 
as suas leis". Ao contrário, diz o papa, fez isto com a finalidade de "encontrar em si a palavra de Cristo, viva e operante no Espírito Santo, e para sondar mais profundamente o mistério, ou seja, o desígnio e a presença de Deus fora e dentro de si".

Na Constituição Apostólica convocatória do Concílio Vaticano II, o papa João XXIII (1997, p. 9-10) expõe os motivos que o levaram à convocação: O mundo passa por uma grave crise que atinge a todos os povos, frente às quais a Igreja católica se sente interpelada e obrigada a dar uma resposta, no sentido de estabelecer um contato entre o mundo moderno e as energias vivificadoras e perenes do Evangelho: Por prescindir de Deus, o progresso da ciência e da técnica traz graves consequências à ordem temporal de tal forma que o avançado progresso material não corresponde a igual progresso no campo moral. Isso faz com que os valores do espírito se enfraqueçam. Com isso, o impulso incontrolável na procura praticamente exclusiva dos gozos terrenos, postos pelo avanço da técnica, com tal facilidade, ao alcance de todos. O papa João XXIII ressalta ainda outro fato completamente novo e desconcertante, que é a existência do ateísmo prático a operar em nível mundial.

Soma-se a isso, outros "sinais dos tempos" (Mt 16,3), apontados por João XXIII (1997, p. 10), que compõem um cenário de trevas que acinzentam a face da terra, apontando para a necessidade de uma resposta da Igreja aos apelos do mundo, por um novo sentido à ordem mundial, os quais são: sucessivas guerras sangrentas em nossos tempos (sobretudo a Primeira e a Segunda Guerra Mundial); ruínas espirituais causadas por inúmeras ideologias e consequências de amargas experiências, mas que deixaram úteis ensinamentos; o progresso científico que possibilitou o homem tecnicamente a criar instrumentos catastróficos (bomba atômica) para destruição em massa, suscitando angustiosas interrogações (eclipsando a razão).

Não nos ateremos aqui em descrever as razões históricas que impediram a Igreja Católica de abrir-se à modernidade, mas em síntese, isso foi motivado por um estado de tensão que se estabeleceu desde o início, entre Igreja e a modernidade que surgia na Renascença, com correntes culturais, políticas e religiosas, com destaque para a Reforma Protestante. Tal estado de tensão se transformaria num profundo fosso, com a Revolução Francesa, impulsionada por ideais iluministas. Esse fechamento à modernidade se deu porque as ideias que dão base ao mundo moderno são contrárias ao depósito fidei, recebido da Igreja pelas mãos dos apóstolos, com missão de guardá-lo, conservando-o intocável ao longo dos séculos. De acordo com Libânio $(2000,13)$, essa resistência da Igreja católica à modernidade, pode tê-la dificultado de perceber-lhes os valores. Por outro lado, como se viu acima, revelou igualmente uma percepção intuitiva de que se ocultavam na mesma germes maléficos.

\section{Abertura da Igreja à luz do Bom Samaritano}


Sinalizando uma tomada de consciência humanista (um novo humanismo na Igreja) por parte dos padres conciliares, o programa pastoral do Concílio Vaticano II está voltado à cultura atual, essencialmente antropocêntrica, tendo se orientado todo ele à utilidade humana. Em seu discurso de encerramento, o papa Paulo VI (1997, p. 669) declarou que o Concílio teve como exemplo e norma norteadora de seus atos, a história do bom samaritano. "Com efeito, um imenso amor para com os homens penetrou totalmente o Concílio. A descoberta e a consideração renovada das necessidades humanas [...] absorveram toda a atenção deste Concílio", a ponto de declarar-se "quase escrava da humanidade", afirmando que "a ideia de serviço ocupou o lugar central" das discussões conciliares, resguardando-se, contudo, em afirmar que "este [Concílio] debruça-se sobre o homem e sobre a terra, mas eleva-se ao reino de Deus". ${ }^{5}$ É com esse espírito que o Vaticano II apresenta a imagem de uma Igreja aberta em relação com o mundo moderno, colocando-se em diálogo com as Igrejas e comunidades cristãs, com as religiões e também com a cultura. ${ }^{6}$ Essa abertura tem sua razão de ser, como o vemos na Redemptoris Missio, um dos documentos do Concílio Vaticano II: "O cristianismo está aberto à fraternidade universal, porque todos os homens são filhos do mesmo Pai e irmãos em Cristo" (RM, n. 43).

Essa abertura de diálogo, contudo, significou também certo modo ruptura com tradições antigas e recentes da própria Igreja que a impediam de exercer sua missão de evangelizar o mundo hoje (LIMA, 2017). Essa ousadia viria a se confirmar na Conferência de Aparecida, quando então se declarou com firmeza que era preciso "abandonar as ultrapassadas estruturas que já não favoreçam a transmissão da fé" (AP n. 365), para não se cair na armadilha de se fechar em torno de si mesmos, devem formar-se "como discípulos missionários sem fronteiras, dispostos a ir 'à outra margem', àquela onde Cristo ainda não é reconhecido como Deus e Senhor, e a Igreja não está presente" (AP n. 376). Isto só se tornará possível com a conversão pastoral e renovação missionária, ou seja, com um "coração universal, aberto a todas as culturas e a todas as verdades, cultivando nossa capacidade de contato humano e diálogo" (DA n. 377).

Sem fazer uso do tradicional recurso da autoridade em sua postura frente à modernidade, reflexo de uma mentalidade restauradora, com sua proposta de realizar um aggiornamento na Igreja católica, João XXIII convocou o concílio Vaticano II, com a finalidade de "trazer a Igreja para dentro do mundo e da cultura de nossos dias" (ZILLES, 1993 , p. 34). Com a pergunta feita na Gaudium et Spes "o que pensa a Igreja do homem"

\footnotetext{
5 Disponível no site: https://w2.vatican.va/content/paul-vi/pt/speeches/1965/documents/hf_pvi_spe_19651207_epilogo-concilio.html. Acessado em: 24/03/2017.

${ }^{6}$ No que pode soar irônico, é que o Vaticano II lança a Igreja católica ao diálogo justamente num momento em que a modernidade, centralizada no indivíduo e na razão autônoma, emancipada que foi da tutela religiosa, tem seus ideais questionados (BEOZZO, 2003, p. 88), apresentando sinais de enfraquecimento, de esgotamento, de exaustão. Com efeito, vivemos hoje uma mudança de época, mais bem descrita como pósmodernidade, termo criado por Jean François Lyotard (2009), que sinaliza o fim das meta-narrativas e que tem por evento simbólico a queda do muro de Berlim.
} 
(GS n. 11), a Igreja católica assume a virada antropológica própria da modernidade, em versão adaptada à teologia, pelo teólogo jesuíta Karl Rahner. Assim, ao ter como ponto de partida para sua ação pastoral o homem em sua situação no mundo, bem como sua obra, como religião da encarnação de Deus, o Vaticano II isenta o Cristianismo de se colocar ao mundo a alternativa simplista "ou Deus ou o homem", afinal, "Deus fez-se homem para que o homem se tornasse divino", decidindo-se, desta forma, a favor do homem. Consequentemente, a Igreja não tem outra escolha: "ou é com Deus a favor do homem ou sem Deus contra o homem" e isto a leva a interessar-se em tudo aquilo que diga respeito ao homem e a sua humanidade (ZILLES, 1993, p. 34).

\section{Chaves de leitura para a compreensão da abertura da Igreja à multiculturalidade}

O Concílio Vaticano II significou um divisor de águas, com uma virada histórica da Igreja católica em sua relação com a cultura moderna. Nessa virada estão presentes duas palavras-chave que são essenciais na compreensão dessa abertura: aggiornamento e diálogo, a que Mário de França Miranda (2006, p.15) atribui como "o sonho de João XXIII" e que sintetizam, portanto, o que pretendia com a realização do Concílio.

\section{Aggiornamento}

Segundo Miranda (2006, p. 16), esta palavra-chave significa atualização, renovação, reforma. Tem por primeiro pressuposto "um descompasso da Igreja com a sociedade envolvente, uma dificuldade, mais experimentada e sentida do que formulada, de proclamar na cultura de então a mensagem evangélica". Isto sinaliza o fim de uma configuração histórica do catolicismo, de uma igreja voltada sobre si mesma, de forma excludente, fechada ao diálogo com o diferente. De acordo com o autor, a ameaça de fragmentação da Igreja, por ocasião da reforma, foi represada pelo Concílio de Trento. Contudo, isso "representou também um catolicismo romano afastado das outras tradições cristãs do ocidente e do oriente, entrincheirado diante da cultura moderna e avesso ao contato com outras culturas nativas". A intensão de João XXIII não era corrigir erros doutrinais ou morais, como se deu nos concílios ecumênicos anteriores, mas "atualizar a mensagem da salvação procurando exprimi-la para o mundo moderno". Esta é, na opinião de Miranda (2006, p. 16), a originalidade do Concílio Vaticano II.

A palavra 'aggiornamento' não se refere a sujeição, nivelamento, pacto ou compromisso da Igreja com o mundo de hoje. Não se trada de uma acomodação do cristianismo ao mundo moderno, nem absorção desse mundo por parte da IgrejaInstituição, num processo de 'eclesiastização' do mundo, formando uma neocristandade. Trata-se sim de colocar a Igreja católica em atitude de escuta, de ir ao encontro, de abrir-se às legítimas exigências do mundo de hoje, que passa por profundas mudanças estruturais e de modos de ser (culturais), inserindo-a no mundo moderno com espírito de ajuda, de 
doação, de caridade total, de diaconia, de serviço. Trata-se, conforme o Cardeal Dom Aloísio Lorscheider (2005, p.18), de “considerar a maneira de pensar do ser humano de hoje, a sua linguagem, o seu modo de ser, para apresentar o Evangelho como única mensagem capaz de salvar". Enfim, aggiornamento é uma abertura crítica ao mundo moderno tendo como critério o Evangelho.

\section{Diálogo}

De acordo com Miranda (2006, p. 17), esta outra palavra-chave é exigência da primeira, aggiornamento, e também da pastoralidade. O diálogo tem por finalidade ser instrumento de conhecimento do público a ser evangelizado pela Igreja. Ele é necessário para que "a sociedade perceba o significado profundo, a dimensão salvífica, bem como a razão de ser da Igreja". Por meio do diálogo com seu interlocutor, a Igreja se posiciona como quem não somente fala, "mas também escuta, aprende, se repensa, se questiona, se modifica, se atualiza" de tal forma que sua autocompreensão é enriquecida, renovada, deixando transparecer melhor sua dimensão institucional. Conforme Miranda (2006, p. 17), o diálogo é "uma realidade profunda e exigente que leva a sério a história, a subjetividade, a sede de comunhão" e esse foi exatamente o objetivo de João XXIII ao convocar o Vaticano II, a fim de que a Igreja realizasse melhor sua missão salvífica.

Detendo-nos um pouco mais sobre essa segunda chave de interpretação, é importante frisar que o diálogo implica o rompimento com uma visão eclesiocêntrica, com a ideia de uma Igreja fechada sobre si mesma, recolocando, consequentemente, em primeiro plano, "o sentido último da instituição eclesial como sacramento da salvação para o mundo, fazendo-a entrar seriamente no desenrolar histórico da humanidade, participar da aventura humana, conviver em sociedade e construir o futuro" (MIRANDA, 2006, p. 17). Enfim, o diálogo implica a saída de uma postura eclesiocêntrica e exclusivista, para uma nova postura, cristocêntrica e inclusivista.

Assim, aggiornamento e diálogo, como palavras-chave interpretativas, constituem "o eixo em torno do qual os temas do ecumenismo, das religiões e das culturas irão se estruturar e deixar assim aflorar a unidade de fundo que os une" (MIRANDA, 2006, p. 18), conforme veremos a seguir.

\section{A Igreja Católica se abre ao diálogo com a pluralidade eclesial e a diversidade religiosa}

Olhando para fora de si, os padres Conciliares procuraram o estabelecimento de diálogo não só com o mundo na sua profanidade, mas igualmente com as suas diversas formas religiosas, desde aquelas próximas em comunhão com a Igreja (Igrejas orientais ortodoxas e as originadas da Reforma) até as tradições religiosas mais distantes 
culturalmente. Assim, estabeleceu-se como meta pastoral, uma posição dialógica com crentes cristãos e não crentes, numa base ética comum e respeitante à liberdade religiosa. A concepção de salvação, até então vista exageradamente referida às dimensões visíveis da Igreja, foi ampliada devido a uma nova percepção da dimensão missionária. Enfim, o Vaticano II reinterpretou em outro horizonte o axioma do $3^{\circ}$ século (dogma de fé para os católicos), extra ecclesiam nulla salus ${ }^{7}$ (LIBÂNIO, 1998, p. 85).

Portanto, acontece uma mudança de foco no que concerne à relação da Igreja católica com os irmãos separados e com os não-cristãos, no que se refere à salvação. Essa mudança corresponde a uma descentralização eclesiológica e uma concentração cristológica que culmina por conceber a Igreja como sendo a universalidade do povo de Deus. A Lumen Gentium expressa essa nova mentalidade inclusivista da Igreja Católica e motiva a todos ao diálogo com o diferente, ao reconhecer que a catolicidade e universalidade da Igreja se estende "a todos os povos da terra" que "são chamados a esta unidade católica do povo de Deus, que prefigura e promove a paz universal", à qual, ainda que de modo diverso, "pertencem ou para a qual se orientam tanto os católicos como todos os cristãos, e mesmo todos os homens em geral, chamados pela graça de Deus à salvação" (LG 13).

A seguir, veremos as três formas de diálogo que a Igreja católica estabelece com a pluralidade eclesial, a diversidade religiosa e com cultura, que evidenciam a mudança de uma visão exclusivista, eclesiocêntrica, própria de uma afirmação monocultural, não cabível para os dias de hoje, para uma visão inclusivista, cristocêntrica, típica de uma realidade multicultural, na qual a Igreja católica é vista como uma dentre uma pluralidade de comunidades eclesiais, que se afirmam como Igreja de Cristo, e de sua parte o Cristianismo como um todo é visto como apenas uma dentre uma diversidade de religiões.

\section{O diálogo com as comunidades cristãs separadas}

\footnotetext{
7 De acordo com o Cardeal francês Yves Congar (1997, p. 55), um dos maiores responsáveis pela abertura ecumênica da Igreja católica, o Vaticano II nos deu uma outra consciência quanto ao passado da verdade dos outros sob o ponto de vista religioso e de suas possibilidades de salvação. "Mantendo sempre as verdades dogmáticas já estabelecidas, acatamos certo número delas de forma diferente", diz o autor, afirmando que hoje não se sustentaria, em "sentido literal material, o enunciado da bula da união dos coptas ou Decreto para os jacobitas, de 4 de fevereiro de 1442, sobre a danação não apenas dos pagãos, mas também dos judeus, dos heréticos e dos cismáticos". Ou seja, para Congar (1997, p. 55), nos dias atuais, o ensinamento oficial da Igreja católica "interdita manter em sentido literal o princípio: Extra Ecclesiam nulla salus". Considera o autor que esse princípio não constitui "uma afirmação sobre a (não)-salvação de quaisquer pessoas, mas uma afirmação sobre a capacidade plenamente católica que possui a Igreja de trazer a todo homem a salvação em sua plenitude".
} 
Embora a abertura ecumênica perpassa diversos documentos conciliares, o decreto Unitatis Redintegratio é o documento dedicado exclusivamente a essa temática, significando a concretização de um desejo de João XXIII. Através deste documento, a Igreja católica reconhece o movimento ecumênico, que surgiu no meio protestante, afirmando-o como fruto da ação do Espírito Santo. A tardia entrada da Igreja ao diálogo ecumênico tem como pressuposto a compreensão de si própria como uma comunhão. "Enquanto se considerava juridicamente uma sociedade perfeita, também se identificava sem mais com a Igreja de Jesus Cristo, de tal modo que fora de si só havia um vazio eclesial". Porém, a partir do momento em que descreve a si própria como constituída por uma pluralidade de elementos tais como: Palavra de Deus, acolhimento na fé, ação do Espírito Santo, sacramentos, ministério ordenado etc, "sem identificar a Igreja de Cristo consigo mesma, ela abre a possibilidade de que alguns desses elementos possam se encontrar fora dela" (MIRANDA, 2006, p. 19).

De fato, em perspectiva de diálogo, num mundo pluralista, o Vaticano II reconhece, no decreto Unitatis Redintegratio, que "dentre os elementos ou bens com que, tomados em conjunto, a própria Igreja é edificada e vivificada, alguns e até muitos e muito importantes podem existir fora do âmbito da Igreja católica" (UR n. 3b). Igualmente declara que "não poucas ações sagradas da religião cristã", que são celebradas por nossos irmãos separados, podem "produzir a vida da graça e devem mesmo ser tidas como aptas para abrir a porta à comunhão da salvação" (UR n. 3c). Em razão disso, as igrejas e comunidades separadas "de forma alguma estão despojadas de sentido e de significação no mistério da salvação". E mais, "o Espírito de Cristo não recusa servir-se delas como de meios de salvação cuja virtude deriva da própria plenitude de graça e verdade confiada à Igreja católica" (UR n. 3d). Assim, a Igreja se vê unida a eles, que são batizados e que tem o nome de cristãos, "embora não professem integralmente a fé ou não guardem a unidade de comunhão com o sucessor de Pedro" (LG 15). Portanto, como dirá mais tarde o papa João Paulo II, "para além dos limites da Comunidade católica, não existe o vazio eclesial" (UUS 13).

Sinalizando uma releitura positiva do dogma extra ecclesiam nula salus, afirmandolhe um caráter inclusivista, como já havia feito anteriormente o papa Pio IX, no século XIX, ${ }^{8}$ em relação aos não-cristãos, o Vaticano II isenta de culpa aqueles que nascem nas comunidades cristãs e que "são instruídos na fé de Cristo", não podendo os mesmos ser "acusados do pecado da separação", razão pela qual "a Igreja católica os abraça com fraterna reverência e amor. Pois aqueles que creem em Cristo e foram devidamente batizados, estão em certa comunhão, embora não perfeita, com a Igreja católica" (UR n. 3a).

8 Encíclica "Quanto conficiamur moerore" aos bispos da Itália, publicada em 10 de agosto de 1863 (DZ 28652867). 


\section{O diálogo com os não-cristãos}

Antes do Vaticano II, as religiões não-cristãs eram vistas pelo cristianismo como realidades inferiores, repleta de falsidades e degenerações, que deveriam desaparecer para dar espaço à única verdade da fé cristã (MIRANDA, 2006, p. 23). Hoje, a salvação dos nãocristãos é vista sob uma nova perspectiva. A Constituição dogmática Lumen Gentium (n. 16) é clara ao mostrar o novo posicionamento da Igreja no Vaticano II, com relação aos não-cristãos. Afirma que aqueles que sem culpa ignoram o Evangelho de Cristo e a sua Igreja, buscando, porém, a Deus com sinceridade do coração, esforçando-se, "sob a ação da graça, por cumprir na vida a sua vontade, conhecida através dos ditames da consciência, também esses podem alcançar a salvação eterna". De igual modo, a divina providência não nega "os meios necessários para a salvação àqueles que, sem culpa, ainda não chegaram ao conhecimento explícito de Deus, mas procuram com a graça divina viver retamente". A Igreja considera "tudo o que neles há de bom e de verdadeiro [...] como preparação ao Evangelho e como dom daquele que ilumina todo o homem para que afinal tenha a vida".

Assim, participam da salvação, a qual, conforme a Gaudium et Spes (n. 22), não se limita somente aos cristãos, mas estende-se a "todos os homens de boa vontade em cujos corações a graça opera de modo invisível", vez que Cristo morreu por todos e uma só é a vocação última do homem, ou seja, divina. Em razão disto os padres conciliares admitem que "o Espírito Santo oferece a todos a possibilidade de se associarem, de modo conhecido por Deus, a este mistério pascal” (GS 22), chamando todos os homens a Cristo, seja pelas sementes do Verbo, seja pela pregação do Evangelho (AG 15).

Por meio da declaração Nostra Aetate, ${ }^{9}$ o menor documento do Vaticano II (com apenas cinco partes), a Igreja se refere de modo inclusivista às religiões não-cristãs, as quais pretende conhecer, compreender e com elas dialogar e cooperar num clima de respeito e de estima mútua, excluindo qualquer forma de discriminação (NA n. 5). O fundamento teológico para essa abertura está logo no início: Com efeito, todos os homens constituem uma só comunidade e uma mesma origem, “uma vez que Deus fez todo o gênero humano habitar a face da terra. Tem igualmente um único fim comum, Deus, cuja Providência, testemunhos de bondade, e planos de salvação abarcam a todos" (NA n.1).

Os padres conciliares dirigem um olhar positivo às religiões universalistas: Hinduísmo, Budismo, Islamismo e Judaísmo, as quais se esforçam "por responder, de vários modos, à inquietação do coração humano, propondo caminhos, isto é, doutrinas e preceitos de vida, como também ritos sagrados" (NA 2). Desta forma, a Igreja católica "não rejeita nada que seja verdadeiro e santo nestas religiões", considerando "com sincero respeito esses modos de agir e viver, esses preceitos e doutrinas", como "um raio daquela

\footnotetext{
${ }^{9}$ A declaração vem marcada "por um otimismo salvífico presente em outros textos conciliares que dizem respeito à salvação dos não-cristãos. O que no passado aparecia apenas como uma possibilidade baseada na misericórdia divina vem nesse concílio incisivamente afirmado" (MIRANDA, 2006, p. 23).
} 
Verdade que ilumina todos os homens" (NA 2). Em razão disso, exorta seus fiéis "a que, com prudência e caridade, por meio do diálogo e da colaboração com os membros das outras religiões, e sempre dando testemunho da fé e da vida cristã", não só reconheçam, mas também "conservem e façam progredir os bens espirituais, morais e os valores socioculturais que nelas se encontram" (NA 2).

Mais conhecido na teologia como princípio da semeadura, em que não se anuncia o Evangelho num vácuo, ou a uma tábua rasa, ${ }^{10}$ ao falar sobre a missão de evangelizar todos os povos em vista ao segundo advento do Senhor e à plenitude escatológica, o Decreto Ad Gentes reconhece que "tudo o que de verdade e de graça" se encontre entre os gentios são "como uma secreta presença de Deus". De igual modo, afirma que "o que de bom há no coração e no espírito dos homens ou nos ritos e culturas próprias dos povos" (AG 9; cf. LG 17). São "sementes do Verbo neles adormecidas"11 que devem ser trazidas à luz, com alegria e respeito (AG 11).

O diálogo inter-religioso "é parte indispensável da relação intercultural, porta de entrada de todo processo evangelizador e fio condutor de toda a relação construtiva entre os sujeitos da evangelização" (AZEVEDO, 2001, p. 26). Esta abertura do Vaticano II é de fundamental importância para o diálogo inter-religioso que segundo Miranda (2006, p. 24) mais que um componente essencial para a evangelização, representa para o concílio a oportunidade de repercutir positivamente dentro do cristianismo. Afinal, "conhecer e respeitar o diferente, sem procurar destruí-lo como uma ameaça à própria identidade, já implica se ver questionado nas próprias convicções, revendo-as à luz dos dados provindos de fora". Ou seja, é necessário que se realize no âmbito da Igreja um diálogo intrareligioso, antes mesmo do diálogo inter-religioso.

Em toda religião há uma tomada de consciência da presença da divindade no mundo. As pessoas acolhem essa divindade como um Outro que vem ao seu encontro. Esse Outro é percebido pela consciência religiosa como transcendente. Trata-se de uma tendência ou um dom que não é criação própria, que direciona o homem ao divino. Em consequência, os atos religiosos são "interpretados pelos que os fazem como uma resposta, uma busca de Deus, provocada pelo próprio Deus, que toma a iniciativa" (LIBÂNIO, 1992, p. 270).

\footnotetext{
${ }^{10}$ Ao evangelizar, a Igreja jamais age no vazio. "Antecede-lhe o Espírito Santo presente antes mesmo da ação evangelizadora da Igreja, como que preparando o campo para a semeadura" (MELO, 1996, p. 68). Esse princípio da semeadura das "sementes do Verbo" aponta para a ação do Espírito Santo em toda a humanidade, mesmo os nos não-cristãos. As 'semina Verbi' "estão difundidas em todas as partes pela ação do Espírito. Assim, antes que chegue a palavra da pregação, já existe uma palavra interior no coração do homem que é fruto da ação do Espírito" (LIBÂNIO, 1975).

11 O papa João Paulo II nos diz que por meio do diálogo inter-religioso "a Igreja pretende descobrir as 'sementes do Verbo', os 'fulgores daquela verdade que ilumina todos os homens' - sementes e fulgores que se abrigam nas pessoas e nas tradições religiosas da humanidade" (RM n. 56).
} 


\section{O diálogo com a cultura}

O Vaticano II deu um novo entendimento na relação da Igreja Católica com a cultura. Assim, diversos textos do Concílio se referem ao diálogo com a cultura. Mesmo sem apresentar uma compreensão adequada da relação fé e cultura, tal como a temos hoje, o Concílio Vaticano II "representa uma tomada de consciência inédita na história da Igreja, que desencadeará todo um processo de reflexão e de ação nos anos posteriores". Em sua análise sobre o diálogo com a cultura, como vimos anteriormente, o Vaticano se afasta de uma concepção elitista e assume uma perspectiva de cunho antropológico (MIRANDA, 2006, p. 25).

A íntima relação entre fé e cultura, propiciada pelo diálogo, tem fundamento teológico na própria encarnação de Cristo nas "condições sociais e culturais" do contexto onde viveu (AG 10). Há de se considerar que Deus sempre se revelou "de acordo com a cultura própria de diversas épocas" (GS 58). Do mesmo modo a Igreja sempre se serviu das culturas na proclamação do Evangelho, na celebração litúrgica bem como na vida da comunidade eclesial, ainda que não se identificasse com qualquer cultura (GS 44; 58).

Segundo a Gaudium et Spes, “é próprio da pessoa humana necessitar da cultura, isto é, de desenvolver os bens e valores da natureza, para chegar a uma autêntica e plena realização", razão pela qual natureza e cultura se encontram intimamente ligadas, pois se refere à vida humana (GS 53). ${ }^{12}$ Sem dúvida, essa nova realidade cultural soa como desafio para a missão evangelizadora da Igreja, lembrando que como artífices e autores da cultura da própria comunidade, os homens e as mulheres devem tomar cada vez mais consciência do "sentido da autonomia e responsabilidade, o qual é de máxima importância para a maturidade espiritual e moral do gênero humano", em vista à construção de "um mundo melhor, na verdade e na justiça" (GS 55). Ao se referirem sobre o progresso da ciência e da técnica, os padres conciliares mostram uma nova sensibilidade frente aos valores e elementos constitutivos da cultura, afirmando que devem ser valorizados, pois tudo "pode constituir certa preparação para a recepção da mensagem evangélica, preparação que pode ser enformada com a caridade divina por aquele que veio para salvar o mundo" (GS 57).

Sobre a relação entre Evangelho e Cultura, conforme a Gaudium et spes, múltiplos são os laços existentes. Ao revelar-se "ao seu povo até a plena manifestação de si no Filho encarnado", Deus se comunicou conforme a cultura própria de cada época. De igual modo, no decorrer da história em diversos condicionalismos a Igreja fez uso dos recursos de diversas culturas fazendo chegar a todos os povos a mensagem de Cristo, com a

\footnotetext{
12 Por seu caráter histórico-social, assumindo frequentemente um sentido sociológico e etnológico, pode-se falar de pluralidade das culturas. "Com efeito, diferentes modos de usar das coisas, de trabalhar e de se exprimir, de praticar a religião e de formar os costumes, de estabelecer leis e instituições jurídicas, de desenvolver as ciências e as artes e de cultivar a beleza, dão origem a diferentes estilos de vida e diversas escala de valores" (GS 53).
} 
finalidade de "explicar, investigar e penetrar mais profundamente e para lhe dar melhor expressão na celebração da liturgia e na vida da multiforme comunidade dos fiéis" (GS 58). Sem estar ligada exclusiva e indissoluvelmente a uma cultura específica, a Igreja é capaz de "entrar em comunicação com as diversas formas de cultura, com o que se enriquecem tanto a própria Igreja como essas várias culturas". No que é função própria da religião cristã, "a boa nova de Cristo renova continuamente a vida e a cultura do homem decaído e combate e elimina os erros e males nascidos da permanente sedução e ameaça do pecado". Expressando bem o princípio da inculturação do Evangelho nas culturas, este tem a capacidade de purificar sem cessar e elevar os costumes dos povos. "Fecunda como que por dentro, com os tesouros do alto, as qualidades de espírito e os dotes de todos os povos e tempos; fortifica-os, aperfeiçoa-os e restaura-os em Cristo" (GS 58).

Por fim, no sentido de harmonização dos diversos aspectos da cultura, considerando sua missão de evangelizar concorrendo para um mundo melhor, de amor, justiça e paz, valorizando a humanização integral, nas dimensões material e espiritual, "a Igreja lembra a todos que a cultura deve orientar-se para a perfeição integral da pessoa humana, para o bem da comunidade e de toda a sociedade". Em razão disso, torna-se necessário "cultivar o espírito de modo a desenvolver-lhe a capacidade de admirar, de intuir, de contemplar, de formar um juízo pessoal e de cultivar o sentido religioso, moral e social". (GS 59). Uma vez que deriva de modo imediato da natureza racional e social do homem (artífice da cultura), a cultura "tem uma constante necessidade de justa liberdade e de legítima autonomia, de agir segundo os seus próprios princípios para se desenvolver. Com razão, pois, exige ser respeitada e goza duma certa inviolabilidade, salvaguardados, evidentemente, os direitos da pessoa e da comunidade, particular ou universal, dentro dos limites do bem comum" (GS 59).

Sem dúvida, o maior desafio para a Igreja, em seu processo de aggiornamento, foi a relação Igreja e sociedade e mais concretamente, Igreja e cultura hodierna. A relação entre fé e cultura sempre se apresentou como uma questão prático-teórica fundamental para a evangelização. Justo González (2011, p. 31), um dos maiores historiadores atuais da Igreja na América Latina, comenta que "cada vez que a mensagem do evangelho atravessa uma fronteira, cada vez que cria raízes em uma nova população, cada vez que é pregada em um novo idioma, coloca-se uma vez mais a questão da fé e da cultura". Esse mesmo autor afirma que tão logo o cristianismo começa a abrir passagem pelo mundo grecoromano, a pergunta apropriada gira em torno de "como os cristãos deveriam ver a cultura desse mundo: deveriam rejeitar tudo que viesse dela como produto do demônio e do erro? Ou seria possível ver nela a mão e a ação de Deus?".

Essa questão volta à tona por volta das grandes épocas missionárias, no século 16 para o catolicismo e no século 19 para o protestantismo. Toda vez que o cristianismo penetrava ou tentava penetrar numa nova cultura, a pergunta que se impunha era de como deveria se comportar perante ela. Ou seja, deveria destruir-se a velha cultura para 
construir, sobre seus escombros, a nova fé? Ou numa visão de acordo com o próprio Evangelho, empenhar-se no sentido de adaptar a pregação e o ensino do Evangelho aos modelos da cultura receptora? Seria o caso de analisar essa cultura, dividindo-a em diversos elementos, a fim de aceitar em seguida uns e rejeitar outros? Em síntese, "a questão da fé e cultura é tema obrigatório para qualquer discussão missiológica" (GONZÁLEZ, 2011, p. 32).

Fé e cultura tem em comum o fato de abranger e tocar a totalidade da pessoa humana. Por isso torna-se importante uma articulação entre as duas. Embora a sensibilidade à cultura tenha caracterizado a evangelização dos tempos da igreja primitiva, nos séculos mais recentes, contudo, a transmissão da fé se deu sem considerar a cultura do outro. Devido à "hegemonia da cultura ocidental na Igreja, durante quase todo o segundo milênio que ora estamos para concluir", a articulação entre fé e cultura eclipsou-se (AZEVEDO, 1991, p. 138). Ainda na década de 1960, Paulo VI entendeu essa dissociação entre fé e cultura como sendo "o drama de nossa época, como o foi de outras também" (EN 29-20).

\section{Conclusão}

A partir do Concílio Vaticano II, temas como o diálogo ecumênico e inter-religioso e a evangelização, em modalidade de inculturação, tem estado presentes na agenda de discussão da Igreja católica, ocupando um maior espaço nos documentos do magistério da Igreja, bem como marcando presença nas grandes reuniões pastorais da hierarquia da Igreja. Os desdobramentos do Vaticano II foram decisivos para a Evangelização e para o diálogo ecumênico e inter-religioso.

No campo da evangelização, a abertura dialógica da Igreja fez com que a evangelização tomasse novos rumos, assumindo uma postura positiva no anúncio do Evangelho às religiões não-cristãs. Mereceu por parte do papa Paulo VI, um documento dedicado exclusivamente a ela: a Evangelii Nuntiandi, publicado logo após o Vaticano II, exclusivamente à evangelização, aprofundando sua índole (18-24), estabelecendo seus conteúdos (25-39) e meios (40-48), bem como seus destinatários (48-58). Esse documento passou por uma adaptação à realidade latino-americana, em Puebla, influenciando os novos rumos da missão evangelizadora. Por fim, mereceu do papa João Paulo II, um ousado projeto de uma Nova Evangelização, lançado em 1983, no Haiti. Desde então, aquele papa, canonizado como santo, não mais parou de falar a Nova Evangelização, tornando-se seu porta estandarte. A mesma viria a se tornar tema central em Santo Domingo, quando então foi adotada como projeto pastoral pelos bispos da América Latina, ali reunidos. Por parte do mundo laico, os leigos criaram um movimento para uma década especial de evangelização, como preparação ao ano 2.000: a “Evangelização 2.000" (PEDRINI, 2002, p. 109). 
No que se refere às três formas de diálogo estabelecidas para a Igreja, pelo Vaticano II, estas estão em estreita relação com a evangelização. O diálogo ecumênico tem sua razão de ser em vista da evangelização. Sua meta é superar as consequências das divisões para anunciar um Cristo que não seja dividido, para assim dar credibilidade ao cristianismo. Nos campos de missão ou evangelização, importa que todos, católicos e protestantes, anunciem um mesmo Cristo, para que o mundo creia (Jo 17,21). Quanto ao diálogo inter-religioso, a evangelização implica uma relação dialogal entre as religiões não-cristãs, com as quais entra em contato. Conforme o papa João Paulo II, na Redemptoris Missio (RM n. 55), “o diálogo inter-religioso faz parte da missão evangelizadora da Igreja" e não contrasta com o anúncio de Cristo.

Concluindo, pode-se afirmar que o Concílio Vaticano II foi decisivo para o relacionamento da Igreja católica com as outras religiões. A mesma entra para o movimento ecumênico, em busca da unidade do Cristianismo, a fim de testemunhar Jesus Cristo ao mundo não-cristão. O dialogar com a pluralidade eclesial e diversidade religiosa passa a ser, irreversivelmente, parte constitutiva da própria identidade católica. Por fim, esta virada de página da Igreja católica que vai do exclusivismo ao inclusivismo religioso, teve repercussões importantes para a reflexão teológica contemporânea, principalmente para um novo ramo da teologia que se afirma cada vez mais nos dias de hoje, que é o da Teologia das Religiões.

\section{Referências}

AZEVEDO, Marcello de Carvalho. Viver a fé cristã nas diferentes culturas. São Paulo: Loyola, 2001. SANCHES, 2004

Marcello S.J. Entroncamentos \& Entrechoques. Vivendo a fé em um mundo plural. São Paulo: Loyola, 1991

BEOZZO, Oscar. O Concílio Vaticano II e a modernidade. In: BOGAZ, S.; COUTO, Márcio A. (Orgs.). II Congresso de Teologia. Vinho Novo em Odres Velhos? Uma igreja para os novos tempos. São Paulo: Loyola, 2003.

BRIGHENTI, Agenor. A missão evangelizadora no contexto atual: realidade e desafios a partir da América Latina. São Paulo: Paulinas, 2006.

CONGAR, Cardeal Yves. Igreja e papado: perspectivas históricas. Tradução de Marcelo Rouanet. São Paulo: Loyola, 1997.

GONZÁLEZ, Justo L. Cultura \& Evangelho: o lugar da cultura no plano de Deus. São Paulo: Hagnos, 2011.

JOÃO XXIII, Papa. Constituição Apostólica com a qual é convocado o Concílio Ecumênico Vaticano II. In: Documentos do Concílio Vaticano II (1962-1975). São Paulo: Paulus, 1997. 
LIBÂNIO, J. B. Teologia da Revelação a partir da modernidade. São Paulo: Loyola, 1992.

. Teologia: Novo paradigma? In: ULLMANN, Reinholdo Aloysio (Org.). Consecratio Mundi. Festschrift em homenagem a Urbano Zilles. Porto Alegre: EDIPUCRS, 1998. Igreja contemporânea: Encontro com a modernidade. São Paulo: Loyola, 2000. Sínodo dos Bispos (1974): Evangelização no Mundo de Hoje. Síntese. Revista de Filosofia. Belo Horizonte: FAJE, v. 2, n. 3 (1975).

LIMA, Luiz Alves de. A catequese do Vaticano II aos nossos dias. São Paulo: Paulus, 2017.

LORSCHEIDER, Dom Aloísio. Linhas mestras do Concílio Ecumênico Vaticano II. In: SANTOS, Manoel Augusto (Org.). Concílio Vaticano II: 40 anos da Lumen Gentium. Porto Alegre: EDIPUCRS, 2005. p. 17-26.

LYOTARD, Jean-François. A Condição Pós-Moderna. Tradução de Ricardo Corrêa Barbosa. Rio de Janeiro: José Olympio, 2009.

MANZATTO, Antônio. Teologia e Literatura. Reflexão teológica a partir da antropologia contida nos romances de Jorge Amado. São Paulo: Loyola, 1994

MIRANDA, Mário de França. A Igreja numa sociedade fragmentada. São Paulo: Loyola, 2006.

PAULO VI. Homilia do papa Paulo VI na conclusão solene do Concílio. In: Documentos do Concílio Ecumênico Vaticano II (1962-1965). São Paulo: Paulus, 1997.

PEDRINI, Alírio José. Evangelizar é fazer Jesus acontecer. São Paulo: Loyola, 2002.

PIETRZAK, Andrzej. Teologia da inculturação segundo Michael Amaladoss e Mário de França Miranda. Lublin: 2010. p. 23-24

SANTORO, Dom Filippo. A Igreja como sacramento: símbolo, memória e evento. In: COSTA, Paulo Cezar (Org.). Sacramentos e evangelização. São Paulo: Loyola, 2004.

ZILLES, Urbano. A modernidade e a Igreja. Porto Alegre: EDIPUCRS, 1993. 